\title{
A Combination of Mentoring-Coaching to Improve Teacher Pedagogic Competence
}

\author{
Ina Fatina Dewi* \\ SMP Kristen Immanuel Pontianak \\ Pontianak, Indonesia \\ *ina,fatina@ski.sch.id
}

\begin{abstract}
Mentoring and coaching are effective ways to affect the workers' growth positively with a purpose to assist them to deal productively with the overwhelming duties and the uncertain environment. This paper aims to share findings from a master's study investigating the impact of a combined mentoring and coaching technique on teacher pedagogic growth. Combining these two techniques is a vigorous technique to approach teachers and encourage them to grow their potential competencies. The method used was action research with a small-scale investigation examining the principal's interaction with two teachers from SMP Immanuel Pontianak. The data needed in this study were collected using an observation rubric and Glickman's quadrant to record the teaching performance, based on two categories (Abstraction and Commitment), and measure teacher pedagogic competence growth. Success indicators from this research were the shifting position in the Glickman's quadrant and/or the increasing scores of each category. The results showed that one of the teachers moved to the higher quadrant and significantly increased the overall score, while the other teacher only experienced a score increment without shifting quadrant. The primary implications to underline were the importance of applying the chosen approaches consistently and considering the teachers' motivation as another determinant success key factor.
\end{abstract}

Keywords-mentoring, coaching, teacher education, pedagogic competences

\section{INTRODUCTION}

Many studies have been done using mentoring and coaching techniques and contributed a piece of evidence that this technique improves work performance in various areas, not only in education [1-4]. Mentoring and coaching in education could raise teachers' self-respect [5], sharpen teachers' reflectivity, change unproductive behavior, and increase job satisfaction [6]. In terms of teachers, one of their productivity lies in their ability to effectively enhances the learning process by providing meaningful teaching [7].

Pedagogic competence showcases teacher capability in performing an effective, creative, and meaningful learning process. Building student experience in solving problems allows students to raise their confidence, build their characters, and improve their cognitive in the $21^{\text {st }}$-century era, whereas technology and globalization exhaust their preparation for future work [8]. Effective teaching requires a thorough evaluation, mostly the school leader's observation and feedback. External feedback allows teachers to see the overlooked aspects in their evaluation. The given feedback is proven to elevate teachers' awareness of their pedagogic competence, which tends to be neglected over time [9]. Therefore, a professional development program to increase teacher pedagogic competence is needed.

Al-Zoubi \& Younes found in their research that one of the causes of low student achievement is students' incapability to follow the curriculum pace [10]. However, Sigrid Blömeke's study revealed that student achievement and the instruction given were significantly affected by teacher quality, including working experience, education background, beliefs and motivations, content knowledge, pedagogical content knowledge, and general pedagogical knowledge [11]. Sigrid's statement was synchronized with Hattie's statement that teacher ability in giving qualified feedback was one of the most influential on student achievement [12]. Teachers with higher pedagogic skills will improve student achievement

Studies about the positive impact of mentoring and coaching have offered many mechanisms to adopt. Some studies stated that mentoring programs were conducted without any particular structure, yet the model could positively impact the professional workers. The mentoring model: Three-stage of goalsetting and self-school-actualization [13], the Menteementor relationship [5], Singaporean Structured Mentoring Program [14], the UK Research Excellence Framework [15], and many others. Although all of the mechanisms above stated that their methods could improve professionalism, the results may bring different impacts without motivation and selfawareness. Despite the mechanisms or frameworks used, mentoring and coaching could help school leaders build a partnership culture that leads teachers to a higher performance level [16].

This paper attempted to include a structure in the mentoring-coaching model and adopted Glickman's Developmental and Clinical Supervision as a combination to improve teacher pedagogic competence. This combined technique is believed to build a personal approach and cope with a broader range of transformation for teachers of SMP Kristen Immanuel Pontianak. The following questions directed the study: (1) How will the chosen approaches and structure 
improve the pedagogic competence? (2) What other factors affect the process of mentoring and coaching?

\section{A. Developmental Supervision as Mentoring Method}

Lutton described mentoring as a process of building a relationship between a professional mentor, who has experience in the area of expertise, and the mentee [17]. Interpersonal approaches in developmental Supervision assemble the mentoring process to build a trustworthy relationship and increase teachers' capabilities.

Glickman categorized teachers into four types based on their development levels [18]:

1) Commitment: describes teachers' knowledge of the student, being flexible and responsive to the class, and other criteria (Table 3).

2) Abstract: conveys teachers' knowledge of content and its pre-requisites, lesson delivery, and other criteria. (Table 4).

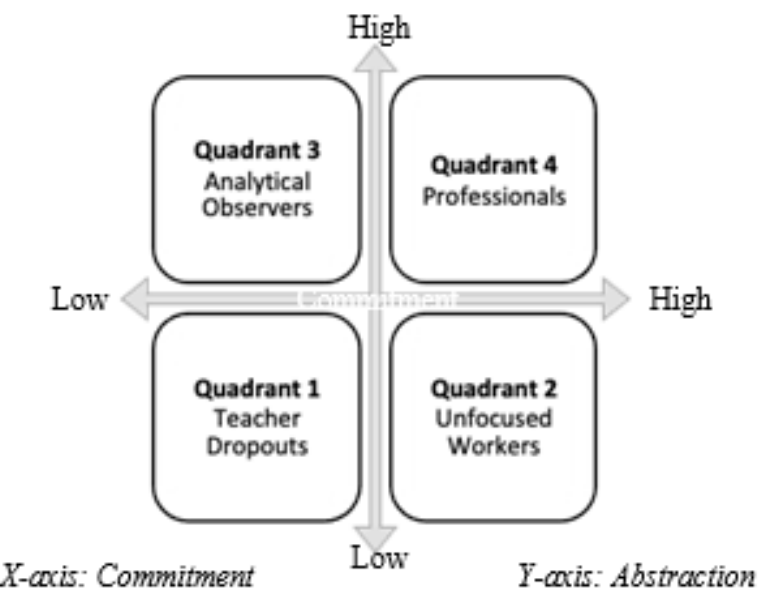

Fig. 1. The quadrant of developmental level.

The four types of a teacher in the quadrant (Figure 1) are Teacher Dropouts (low in both Abstract and Commitment), Unfocused Workers (low mastery in content and pedagogic, but highly committed to helping students), Analytical Observers (capable of being a teacher, but low Commitment), and Professionals (outstanding in both categories).

TABLE I. APPROACHES AND EXPECTED OUTCOMES

\begin{tabular}{|l|l|l|}
\hline $\begin{array}{c}\text { Quad- } \\
\text { rant }\end{array}$ & $\begin{array}{l}\text { Interpersonal } \\
\text { approach }\end{array}$ & \multicolumn{1}{|c|}{ Meeting Outcome } \\
\hline 1 & $\begin{array}{l}\text { The directive- } \\
\text { control }\end{array}$ & $\begin{array}{l}\text { The supervisor decides every plan. The } \\
\text { adopted behaviors used: directing, } \\
\text { standardizing, and reinforcing. }\end{array}$ \\
\hline 2 & $\begin{array}{l}\text { The directive- } \\
\text { informational }\end{array}$ & $\begin{array}{l}\text { The supervisor suggests the plan options. } \\
\text { The adopted behaviors used: presenting, } \\
\text { problem-solving, and negotiating. }\end{array}$ \\
\hline 3 & Collaborative & $\begin{array}{l}\text { Both supervisor and teacher design the } \\
\text { mutual plan. The adopted behaviors used: } \\
\text { clarifying, encouraging, and reflecting. }\end{array}$ \\
\hline 4 & Non-directive & $\begin{array}{l}\text { The teacher self-consciously plans the next } \\
\text { actions. The adopted behaviors used: } \\
\text { listening, clarifying, and reflecting. }\end{array}$ \\
\hline
\end{tabular}

Table 1 describes the interpersonal approaches used according to the specific quadrant to gain certain outcomes. The following behaviors are the options to be applied in every meeting: listening, clarifying, encouraging, reflecting, presenting, problem-solving, negotiating, directing, standardizing, and reinforcing $[18,19]$. These behaviors will open discussion, encourage teachers to express themselves, sharpen teachers' perspectives, and lead them to think about a plan to improve their competencies.

\section{B. Clinical Supervision as Coaching Structure}

Coaching has a similar meaning to mentoring, however, the coach has a different area of expertise with the coachee [17]. Coaching focuses more on goal setting and short-term achievements rather than approaches for professional improvement. Similar to coaching, clinical Supervision (5stage structure) allows a supervisor to collect evidence, highlight aspects to improve, plan the actions, and give constructive feedback.

Sarfo and Cudjoe postulated that a reliable supervisor must provide feedback and assistance; they must not only focus on teacher failures and mistakes [20]. Teachers should be open to discussing the supervisor's observation results, diagnosis, and suggestions for solutions. In structured supervision sessions, the teacher and supervisor define common objectives as the propeller to conduct observation and realize its importance. Therefore, there will be no 'bosses' and 'condemned' subjects along with the research.

Glickman defined the structure of clinical Supervision as follows $[18,19]$ :

1) Pre-conference with a teacher: In this stage, a supervisor should share and discuss the instrument of observation, the research's purpose, and the proposed timeline.

2) Observation of classroom instruction: An observer will collect evidence during the learning process in the classroom. An observer needs to differentiate the descriptions from interpretations as evidence of observation. Therefore, the observer's assumptions will not interfere with the evidence collected.

3) Analyzing and interpreting the observation and determining conference approach: Based on the collected evidence, the supervisor needs to analyze the artifacts, decide the teacher's position in the quadrant, and select a suitable interpersonal approach. If possible, a supervisor may hand over a copy of the observation result to the teacher and ask them to bring their interpretation to the post-conference meeting.

4) Post-conference with the teacher: After the reflection session, this meeting will have an improvement plan as its primary outcome. Firstly, a discussion should be exposing interpretation from both sides. Using the appropriate behaviors, the supervisor and teacher develop a plan for future improvement. It could be mutually decided together or 
suggested by one of the sides, either supervisor or teacher. Also, in this stage, the supervisor needs to assist teachers who need improvement in certain aspects, e.g., training/workshop, peer-teaching, reading assignments on related theories.

5) Critique of previous four steps: During the final stage, both supervisor and teacher review the four previous stages about the instruments or procedures used, valuable insights to note down, or any changes required for the next Supervision. The session should be held a few days after the postconference meeting, and it needs not be a formal session.

\section{METHODS}

This action research investigates whether the use of developmental supervision approaches in a 5-stage clinical supervision structure for teacher mentoring and coaching could improve their pedagogic competence in SMP Kristen Immanuel Bilingual Pontianak (SMP IBC).

TABLE II. NUMBER OF STUDENTS WHO CHOSE THEIR MOST DIFFICULT SUBJECT

\begin{tabular}{|l|l|l|l|l|}
\hline Subjects & Math & Science & English & \multicolumn{1}{c|}{$\begin{array}{c}\text { Total } \\
\text { Students }\end{array}$} \\
\hline Grade 7 & 36 & 58 & 6 & 100 \\
\hline Grade 8 & 30 & 52 & 17 & 99 \\
\hline Grade 9 & 35 & 64 & 2 & 101 \\
\hline
\end{tabular}

SMP IBC has 12 subjects in its curriculum, and there are only three subjects considered as challenging ones: Science, Mathematics, and English. Based on a monthly survey collecting information from students, Science is the most challenging subject (Table 2). Students' achievement in the science class in 2014-2015 was under the minimum requirement, which means less than $70 \%$ of the class passed Science. Thus, this research conducted an in-depth study of two science teachers named subject $\mathrm{X}$ and subject $\mathrm{Y}$.

The data collection were collected using the following instruments: (1) classroom observation rubrics, which consists of two categories (Abstraction and Commitment) with eight aspects for each category as shown in table 3 and 4 ; (2) indepth interview sessions with two subjects; (3) supervisor's anecdotal record of writing down teachers' responses when principal applied certain behaviors during the meeting session; and

A rubric was developed to assess teachers' developmental level: Abstraction and Commitment. Each category has eight aspects of measuring in detail (Table 3 and 4). The rubric was developed by comparing and combining the common aspects from Regulation of the Minister of National Education (Permendiknas) No. 16/2007 and the Danielson Framework for Teaching [21]. The reason to combine these two evaluation instruments was to gain contextual success criteria for teaching. Then, plotting teachers' positions based on teachers' score results in the quadrant and measure their progress throughout the research. It is categorized as 'LOW' level if the score conversion range from $0 \%$ to $50 \%$, while the 'HIGH' level is from $51 \%-100 \%$. This grading counts both categories.

\section{RESULTS AND DISCUSSION}

\section{A. Cycle 1}

The first stage was Pre-Conference. Initially, the supervisor explained the purposes of mentoring and coaching as supervision techniques. Also, both subjects need to grasp the complete supervision process, which might need a long term. Another point to discuss was the rubric developed for this research to conduct the observation. Based on the observation instrument used, both subjects understood the success criteria.

TABLE III. COMMITMENT SCORE

\begin{tabular}{|l|c|c|}
\hline \multicolumn{1}{|c|}{ Aspect } & X & Y \\
\hline Knowledge of Student (K1) & 2 & 1 \\
\hline Classroom Management (K2) & 2 & 2 \\
\hline Knowledge of Student Achievement (K3) & 1 & 2 \\
\hline Effective Feedback (K4) & 2 & 3 \\
\hline Flexible and Responsive (K5) & 3 & 3 \\
\hline Handling Student Behavior (K6) & 2 & 3 \\
\hline Student Motivation (K7) & 2 & 2 \\
\hline Self-Reflection (K8) & 1 & 1 \\
\hline Score & $\mathbf{1 5}$ & $\mathbf{1 7}$ \\
\hline
\end{tabular}

Score Conversion $=($ Score $/$ Total $) \times 100 \%$

Subject $X=(15 / 32) \times 100 \% \approx 47 \% *)$

Subject $Y=(17 / 32) \times 100 \% \approx 53 \% *)$

TABLE IV. ABSTRACTION/EXPERTISE SCORE

\begin{tabular}{|l|c|c|}
\hline \multicolumn{1}{|c|}{ Aspect } & X & Y \\
\hline Content and Pedagogical Knowledge (A1) & 2 & 1 \\
\hline Lesson Plan Design (A2) & 1 & 1 \\
\hline Learning Objective (A3) & 1 & 1 \\
\hline Effective Instruction (A4) & 2 & 1 \\
\hline Questioning and Discussion Skill (A5) & 3 & 1 \\
\hline Model Learning (A6) & 3 & 2 \\
\hline Conclusion and Confirmation (A7) & 2 & 2 \\
\hline Assessment (A8) & 3 & 1 \\
\hline Score & $\mathbf{1 7}$ & $\mathbf{1 0}$ \\
\hline
\end{tabular}

Score Conversion $=($ Score $/$ Total $) \times 100 \%$

Subject $X=(17 / 32) \times 100 \% \approx 53 \% *)$

Subject $Y=(10 / 32) \times 100 \% \approx 31 \% *)$

*) Score Conversion

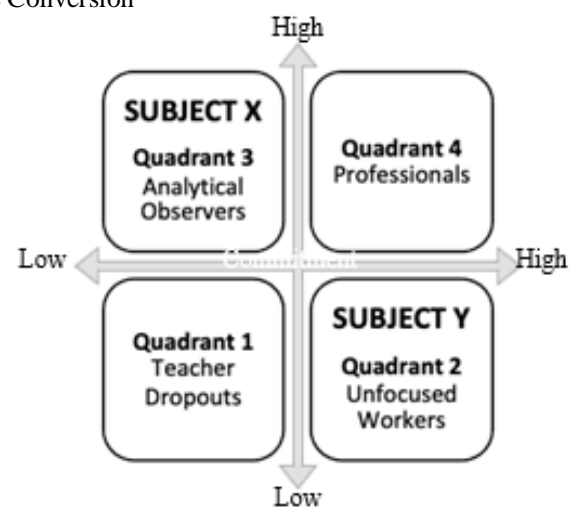

Fig. 2. The quadrant of subject $\mathrm{X}$ and $\mathrm{Y}$. 
The two next stages were classroom observation and analysis-interpretation. The supervisor objectively observed the lesson plan implemented in the classroom, the quality of instruction, and teachers' content knowledge. It was crucial to remove assumptions while writing down all the findings (descriptions and interpretation). These findings were analyzed and used to set the initial data. The preliminary data (Table 3 and 4) were collected to define teachers' position in quadrant (Figure 2) and the interaction approaches. Collaborative and Directive-Informational approaches were consecutively used to communicate with Subject X (high Abstract/Expertise, low Commitment) and Subject Y (low Abstract/Expertise, high Commitment).

In the Post Conference stage, the supervisor shared the observation results and asked about their perspectives, interpretations, feeling, and self-reflection for the last observation. While having this session, it is vital for building trust in every interaction. Dealing with subject $X$, the supervisor asked if there is any aspect to improve or possible solutions (Collaborative approach). On the other hand, the supervisor had figured out a few solutions to offer to Subject $\mathrm{Y}$ (Directive-Informational).

At the end of the session, Subject $X$ proposed focusing on the aspects of her Commitment, specifically the knowledge of students, and log in to her journal (self-reflection); Subject X wrote those proposals as an action plan. There were three options offered for Subject Y, namely, designing an effective lesson plan, questioning, discussion skill, and student assessment. Those options were retrieved from her low score in abstraction/expertise. Eventually, she chose to re-design lesson plans and practice them out by peer teaching.

Both subjects implemented the action plan and the chosen action in the classroom until the end of March (4 weeks). Before this first cycle ended, there were five recorded scores for classroom observation to measure each subject's progress. This cycle was closed with a critique session.

\section{B. Cycle 2}

The pre-conference of this cycle was combined with a critique session in cycle 1 . We reflected on our past cycle by analyzing the researcher's approaches (collaborative and directinformational), the effectiveness of the structure of clinical Supervision, and the treatment given to improve their skills. Both subjects claimed that they enjoyed the Supervision, felt be appreciated, and some of their issues, such as student motivation or formative assessment, were eliminated. They also affirmed that a leader's presence brought massive support for them. The chosen approaches were useful for building the relationship and subjects' confidence, leading to their pedagogic improvement (Table 5). Therefore, in the second cycle, there was no alteration in approaches and structure. The focus of observation in this cycle was to maintain the progress they had made.

Minor corrections were discussed during the postconference session. Subject $\mathrm{X}$ remained focus on her
Commitment; She still had to improve her students' motivation by developing a warm interaction and active engagement. Although there was no significant issue in her abstract category, her instructions were quite burdensome and challenging for students to understand. On the other side, subject $\mathrm{Y}$ lingered on her struggle with the abstract category. Carrying on the workshop session on lesson plan design and peer teaching, she also had to explore the questioning skill and the variety of learning models. These two aspects in her abstract had become our main concern.

Finally, in the last session, we reevaluated the whole process of cycle 2 and analyzed the approaches chosen from Developmental Supervision (collaborative and directinformational), the 5-stage structure of clinical Supervision, and the training or workshop given. The increasing scores accentuated the focus of this cycle 2 .

TABLE V. SUBJECTS' COMMITMENT PROGRESS

\begin{tabular}{|l|l|l|l|l|l|l|}
\hline \multirow{2}{*}{ Aspect } & \multicolumn{3}{|c|}{ Subject X } & \multicolumn{3}{c|}{ Subject Y } \\
\cline { 2 - 7 } & $\begin{array}{c}\text { Prelimi } \\
\text { nary }\end{array}$ & $\begin{array}{c}\text { Av. } \\
\text { Cycle } \\
\boldsymbol{I}\end{array}$ & $\begin{array}{c}\text { Av. } \\
\text { Cycle 2 }\end{array}$ & $\begin{array}{c}\text { Prelimi } \\
\text { nary }\end{array}$ & $\begin{array}{c}\text { Av. } \\
\text { Cycle } \\
\boldsymbol{I}\end{array}$ & $\begin{array}{c}\text { Av. } \\
\text { Cycle 2 }\end{array}$ \\
\hline K1 & $50 \%$ & $50 \%$ & $75 \%$ & $25 \%$ & $50 \%$ & $50 \%$ \\
\hline K2 & $50 \%$ & $50 \%$ & $50 \%$ & $50 \%$ & $50 \%$ & $50 \%$ \\
\hline K3 & $25 \%$ & $50 \%$ & $50 \%$ & $50 \%$ & $50 \%$ & $50 \%$ \\
\hline K4 & $50 \%$ & $50 \%$ & $50 \%$ & $75 \%$ & $75 \%$ & $75 \%$ \\
\hline K5 & $75 \%$ & $50 \%$ & $50 \%$ & $75 \%$ & $50 \%$ & $75 \%$ \\
\hline K6 & $50 \%$ & $50 \%$ & $50 \%$ & $75 \%$ & $75 \%$ & $50 \%$ \\
\hline K7 & $50 \%$ & $50 \%$ & $50 \%$ & $50 \%$ & $50 \%$ & $50 \%$ \\
\hline K8 & $25 \%$ & $50 \%$ & $50 \%$ & $25 \%$ & $50 \%$ & $50 \%$ \\
\hline Total & $47 \%$ & $50 \%$ & $53 \%$ & $53 \%$ & $56 \%$ & $56 \%$ \\
\hline
\end{tabular}

TABLE VI. SUBJECTS' ABSTRACTION/EXPERTISE PROGRESS

\begin{tabular}{|l|l|l|l|l|l|l|}
\hline \multirow{2}{*}{ Aspect } & \multicolumn{3}{|c|}{ Subject X } & \multicolumn{3}{c|}{ Subject Y } \\
\cline { 2 - 7 } & $\begin{array}{c}\text { Prelimi } \\
\text { nary }\end{array}$ & $\begin{array}{c}\text { Av. } \\
\text { Cycle 1 }\end{array}$ & $\begin{array}{c}\text { Av. } \\
\text { Cycle 2 }\end{array}$ & $\begin{array}{c}\text { Prelimi } \\
\text { nary }\end{array}$ & $\begin{array}{c}\text { Av. } \\
\text { Cycle 1 }\end{array}$ & $\begin{array}{c}\text { Av. } \\
\text { Cycle 2 }\end{array}$ \\
\hline A1 & $50 \%$ & $50 \%$ & $50 \%$ & $25 \%$ & $50 \%$ & $50 \%$ \\
\hline A2 & $25 \%$ & $50 \%$ & $50 \%$ & $25 \%$ & $50 \%$ & $50 \%$ \\
\hline A3 & $25 \%$ & $75 \%$ & $75 \%$ & $25 \%$ & $50 \%$ & $50 \%$ \\
\hline A4 & $50 \%$ & $50 \%$ & $50 \%$ & $25 \%$ & $50 \%$ & $50 \%$ \\
\hline A5 & $75 \%$ & $75 \%$ & $75 \%$ & $25 \%$ & $25 \%$ & $25 \%$ \\
\hline A6 & $75 \%$ & $75 \%$ & $75 \%$ & $50 \%$ & $25 \%$ & $25 \%$ \\
\hline A7 & $50 \%$ & $75 \%$ & $75 \%$ & $50 \%$ & $50 \%$ & $50 \%$ \\
\hline A8 & $75 \%$ & $50 \%$ & $50 \%$ & $25 \%$ & $50 \%$ & $50 \%$ \\
\hline Total & $\mathbf{5 3 \%}$ & $\mathbf{6 3 \%}$ & $\mathbf{6 3 \%}$ & $\mathbf{3 1 \%}$ & $\mathbf{4 4 \%}$ & $\mathbf{4 4 \%}$ \\
\hline
\end{tabular}

Both subjects showed increasing competencies, whether shown with a changing position in the quadrant or the increasing score. Subject X scored $53 \%$ in the Commitment $(\mathrm{HIGH})$ and $63 \%$ for her Abstract $(\mathrm{HIGH})$. These score combinations put Subject $\mathrm{X}$ into a new quadrant, which meant she moved from quadrant III (Analytical Worker) to quadrant IV (Professionals). On the other hand, Subject Y remained in her current position as the Unfocused Workers; her scores were not significantly high enough to help her move quadrant. Nevertheless, she showed progress on those scores: $56 \%$ for the Commitment (HIGH) and 44\% for her Abstraction (LOW). In conclusion, the mentoring and coaching technique had 
improved teacher pedagogic competence. Although, some factors might affect the progress.

Subject X's scores raised 6-10\% in both categories, which meant her action plans did help her improve her performance. This finding was supported with the rising score in her K8 aspect as she started to be familiar with reflecting on her classroom right after it was over. She acknowledged her notes about students' misconceptions and responses. Then, he re-used her stimulus and reactions to see whether the engagements with students increased. In her Abstraction, the A3 and A7 aspects improved vastly. Before the observation and the supervisor's feedback, she came to the classroom without setting any target for students to achieve.

There was no fierce correction made during the clinical supervision stages, while the supervisor applied the Collaborative approach. Subject $X$ analyzed the observation results with the supervisor and stated that she had an issue with interaction. The supervisor triggered her with prompting questions and asked her to figure out the solutions. Referring to the supervisor's anecdotal record, Subject $X$ claimed that feedback she received helped her identified the mistakes and the coaching sessions intrigued her thinking to gain ideas for altering her teaching practices. By giving her the freedom to choose and sharpening her thoughts, the Collaborative approach was reasonably fit for Subject X. She has the motivation to grow professionally and is aware that her alterations will positively impact her student achievement.

On the other hand, Subject $\mathrm{Y}$ focused her improvement on Abstraction after the preliminary observation, as she was aware of her lack of content mastery. She struggled with designing lesson plans and only had a little clue how to insert inquirybased learning into her questions and discussion. Her action plan of practicing peer teaching went stagnant. There was no significant improvement seen during those sessions. She required constant feedback, and without it, she returned to lecturing for almost the entire hour. Some examples and more in-depth feedback were given to enrich her practices (at least 12 peer teaching sessions had been conducted); however, her A3, A5, and A6 scores showed slight progress only.

Referring to the supervisor's journal, Subject Y tended to be a doubtful person. She preferred to be a receiver rather than a doer; thus, the chosen approach matched her personality. The supervisor gave suggestions to help her acquire ideas during the mentoring process. Subject Y wrote that she felt assistance and gained more ideas in the peer teaching sessions. Although she admitted that she needed more time to get used to the inquiry learning, prompting questions, and altering teaching scenarios at the spot. Subject $\mathrm{Y}$ also mentioned that this coaching structure helped her see the overlooked mistakes and design correcting actions after the sessions.

This combined mentoring and coaching method provides a range of behaviors to approach teachers personally. The result would be different if the supervisor forced both teachers to follow her instructions. Teachers' initiatives would be disregarded, and they felt unappreciated. Furthermore, this method allows the supervisor to observe, record, and discuss the classroom facts with teachers. Both subjects acknowledged the given structure as a helpful method in which their mistakes were observed by other people and received constructive feedback.

\section{CONCLUSION}

This study contributed to the existing findings of how mentoring and coaching successfully increase competencies. This combination of Developmental (the approaches) and Clinical (the structure) Supervision improved teacher pedagogic competence. The approaches used helped teachers identify and interpret the issue in their classroom and then get possible solutions during the post-conference. The behaviors that the supervisor chose abolished the distance between a leader and teachers, built confidence within themselves in finding solutions and admitting their mistakes, and raising the sense of belonging to the classroom. The structure allowed the supervisor to observe, analyzed, and discussed the issues with subjects. Providing treatment also seemed right on target. By having this combined method, the development program will be a bull-eye to solve teachers' problems. This program will be more effective because various topics could be given in a varied time frame, compared to the training or workshop decided by the Human Resource, without considering the teachers' need.

Besides the effective supervision methods, the success of this research was also affected by other factors-first, the leaders/supervisor's consistency in applying the chosen approaches/behaviors - secondly, the urge to change within the subject. If the subject were reluctant to learn and upgrade themselves, this research would have been scattered at stage 1 . These findings were aligned with Tee $\mathrm{Ng}$ 's statement that professional development can only happen when teachers rely on their critical thinking, not just a structure of mentoringcoaching [14]

However, this study was conducted with only two subjects. It is a limited scope to generalize the findings. It is a personal admittance that mentoring and coaching a person took a lot of time and energy. Therefore, further research is needed to validify these findings, and it should include more researchers and subjects. Moreover, a more profound research about growing inner motivation will lead teachers to be SelfRegulated Learning people.

\section{ACKNOWLEDGMENT}

This study had fully supported by Sekolah Kristen Immanuel Pontianak, specifically SMP Kristen Immanuel and the two teachers. I would also be thankful for all assistance, support, and advice to complete this study. I appreciate it. 


\section{REFERENCES}

[1] P. Lord, M. Atkinson, and H. Mitchell, "Mentoring and coaching for professionals: A study of the research evidence," Variations, vol. 1, no. 4, 2008.

[2] P. Núñez-Cacho Utrilla and F. Á. Grande Torraleja, "The importance of mentoring and coaching for family businesses," J. Manag. Organ., vol. 19, no. 4, pp. 386-404, 2013, doi: 10.1017/jmo.2013.28.

[3] C. Zehntner and J. A. McMahon, "Mentoring in coaching: the means of correct training? An autoethnographic exploration of one Australian swimming coach's experiences," Qual. Res. Sport. Exerc. Heal., vol. 6, no. 4, pp. 596-616, 2014, doi: 10.1080/2159676X.2013.809376.

[4] A. Ganesh, A. Bozas, M. Subban, and E. Munapo, "The benefits of mentoring and coaching in the public sector," J. Gov. Regul., vol. 4, no. 3, pp. 16-29, 2015, doi: 10.22495/jgr_v4_i3_p2.

[5] R. G. Carmel and M. W. Paul, "Mentoring and coaching in academia: Reflections on a mentoring/coaching relationship," Policy Futur. Educ., vol. 13, no. 4, pp. 479-491, 2015, doi: 10.1177/1478210315578562.

[6] P. Allan, "The benefits and impacts of a coaching and mentoring programme for teaching staff in secondary school ," Int. J. Evid. Based Coach. Mentor., vol. 5, no. 2, pp. 12-21, 2007.

[7] J. Lonergan, G. Mooney Simmie, and J. Moles, "Mentoring to Reproduce or Change Discourse in Schools," Int. J. Mentor. Coach. Educ., vol. 1, no. 2, pp. 104-119, 2012, doi: $10.1108 / 20466851211262851$

[8] C. L. Scott, “The Futures of Learning,” 13, 2015.

[9] L. Leonard, "Kompetensi Tenaga Pendidik di Indonesia: Analisis Dampak Rendahnya Kualitas SDM Guru dan Solusi Perbaikannya," Form. J. Ilm. Pendidik. MIPA, vol. 5, no. 3, pp. 192-201, 2016, doi: 10.30998/formatif.v5i3.643

[10] S. M. Al-zoubi and M. A. B. Younes, "Low Academic Achievement : Causes and Results," Theory Pract. Lang. Stud., vol. 5, no. 11, pp. 2262-2268, 2015, doi: 10.17507/tpls.0511.09.
[11] Sigrid Blömeke, R. V. Olsen, and U. Suhl, "Relation of Student Achievement to the Quality of Their Teachers and Instructional Quality," in Teacher Quality , Instructional Quality and Student Outcomes, T. Nilsen and J.-E. Gustafsson, Eds. Springer Open, 2016, pp. 21-50.

[12] J. A. Hattie, Visible learning: A synthesis of over 800 meta-analyses relating to achievement. Madison Avenue, New York, NY: Routledge, 2009.

[13] C. Rhodes, "Coaching and mentoring for self-efficacious leadership in schools,” Int. J. Mentor. Coach. Educ., vol. 2, no. 1, pp. 47-63, 2013, doi: 10.1108/20466851311323087.

[14] P. Tee Ng, "Mentoring and coaching educators in the Singapore education system,” Int. J. Mentor. Coach. Educ., vol. 1, no. 1, pp. 24-35, 2012, doi: 10.1108/20466851211231602.

[15] M. Jones, "Mentoring and coaching in education practitioners' professional learning," Int. J. Mentor. Coach. Educ., vol. 4, no. 4, pp. 293-302, 2015, doi: 10.1108/IJMCE-09-2015-0027.

[16] E. Parsloe and M. Leedham, Coaching \& Mentoring: Practical conversations to improve learning, Second. London and Philadelphia: Koran Page, 2009.

[17] M. Chu, Developing mentoring and coaching relationships in early care and education: A reflective approach, First. New Jersey, USA.: Pearson, 2014

[18] C. D. Glickman, Leadership for learning, 1st ed. Alexandria, Virginia USA: Association for Supervision and Curriculum Development, 2002

[19] C. D. Glickman, S. P. Gordon, and J. M. R. Gordon, The Basic Guide to Supervision and Instructional Leadership, Third. New Jersey: Pearson, 2013.

[20] F. K. Sarfo and B. Cudjoe, "Supervisors ' Knowledge and Use of Clinical Supervision to Promote Teacher Performance in basic schools," Int. J. Educ. Res., vol. 4, no. 1, pp. 87-100, 2016.

[21] C. Danielson, "The Framework For Teaching: Evaluation Instrument," 2013 